\title{
Inhibition of inflammation by pentosan polysulfate impedes the development and progression of severe diabetic nephropathy in aging C57B6 mice
}

\author{
Jin $\mathrm{Wu}^{1}$, Tian-jun Guan ${ }^{2}$, Shirong Zheng ${ }^{3}$, Fabrizio Grosjean ${ }^{1}$, Weicheng Liu ${ }^{4}$, Huabao Xiong ${ }^{4}$, Ronald Gordon ${ }^{5}$, \\ Helen Vlassara ${ }^{1}$, Gary E Striker ${ }^{1,6}$ and Feng Zheng ${ }^{1,7}$
}

Inflammation has a key role in diabetic nephropathy (DN) progression. Pentosan polysulfate (PPS) has been shown to decreases interstitial inflammation and glomerulosclerosis in 5/6 nephrectomized rats. Since PPS has an excellent long-term safety profile in interstitial cystitis treatment, and we recently found that old diabetic C57B6 mice develop DN characterized by extensive tubulointerstitial inflammatory lesions that mimics human DN, we examined the effect of PPS on old diabetic mice. We also examined the anti-inflammatory properties of PPS in renal cells in vitro. Diabetes was induced with streptozotocin in 18 months female (early aging) C57B6 mice. Mice were then randomized to receive oral PPS ( $25 \mathrm{mg} / \mathrm{kg} /$ day) or water for 4 months. The effect of PPS on NF- $\kappa$ B activation and on TNF $\alpha$, high glucose or advanced glycation end products (AGEs) stimulated proinflammatory gene expression in renal cells was examined. We found that PPS treatment preserved renal function, significantly reduced albuminuria, and markedly decreased the severity of renal lesions, including tubulointerstitial inflammation. PPS also reduced upregulation of TNF $\alpha$ and proinflammatory genes in aging diabetic kidneys. Furthermore, PPS suppressed NF- $\kappa$ B, decreased the proinflammatory actions of TNF $\alpha$, and decreased high glucose and AGEs stimulated MCP-1 production in vitro. Finally, PPS decreased TNF $\alpha$-induced increase in albumin permeability in podocyte monolayers. In conclusion, PPS treatment largely prevents the development/progression of nephropathy in aging diabetic mice. As this may be mediated by suppression of TNF $\alpha$, high glucose, and AGE-stimulated NF- $\kappa$ B activation and inflammation in vitro, the in vivo blockade of DN may be due to the anti-inflammatory properties of PPS.

Laboratory Investigation (2011) 91, 1459-1471; doi:10.1038/labinvest.2011.93; published online 1 August 2011

KEYWORDS: aging; diabetic nephropathy; inflammation; PPS; TNF $\alpha$

Diabetic nephropathy (DN) is the leading cause of end-stage renal disease. ${ }^{1}$ Currently, one of the standards of care for DN patients includes blockade of angiotensin II by angiotensinconverting enzyme inhibitor (ACEI) and/or angiotensin receptor blocker (ARB). Both ACEI and ARB have been shown to slow the progression of DN to some degree. ${ }^{2-4}$ As most patients continue to progress to renal failure, ${ }^{5}$ new therapeutic agents are urgently needed.

Multiple pathways, including dysregulation of renal vasculature, activation of protein kinase $\mathrm{C}$, increased transforming growth factor $\beta$, accumulation of advanced glycation end products (AGEs) and excessive oxidative stress have all been implicated in the pathogenesis of DN. ${ }^{6-9}$ Growing evidence also supports an important role for chronic inflammation in DN progression..$^{10,11}$ For instance, inflammation is critically involved in tubulointerstitial lesions, a key component in renal function decline.

Although the detailed inflammatory signaling pathway(s) involved in the pathogenesis of DN are largely unclear, several anti-inflammatory drugs, such as the inhibitor(s) of cyclooxygenase 2 and rapamycin have been tested either experimentally or clinically for the management of $\mathrm{DN} .{ }^{12,13}$

\footnotetext{
${ }^{1}$ Division of Experimental Diabetes and Aging, Department of Geriatrics, Mount Sinai School of Medicine, New York, NY, USA; ${ }^{2}$ Department of Nephrology, Zhongshan Hospital, Xiamen University School of Medicine, Xiamen, Fujian, China; ${ }^{3}$ Department of Pediatrics, University of Louisville, Louisville, KY, USA; ${ }^{4}$ Immunobiology Institute, Mount Sinai School of Medicine, New York, NY, USA; ${ }^{5}$ Department of Pathology, Mount Sinai School of Medicine, New York, NY, USA; ${ }^{6}$ Division of Nephrology, Department of Medicine, Mount Sinai School of Medicine, New York, NY, USA and 'Department of Nephrology, Dongfang Hospital, Xiamen University, Fuzhou, Fujian, China Correspondence: Dr F Zheng, MD, Division of Experimental Diabetes and Aging, Department of Geriatrics, Mount Sinai School of Medicine, Box 1640, One Gustave Levy Place, New York, NY 10029, USA.
}

E-mail: feng.zheng@mssm.edu

Received 10 September 2010; revised 17 November 2010; accepted 30 November 2010 
Pentosan polysulfate (PPS) is a mixture of semisynthetic sulfated polyanions that is approved by the FDA as an only oral medication for the treatment of interstitial cystitis, an inflammatory-like disease. ${ }^{14}$ The mechanism of antiinflammatory action of PPS is not clear. It is reported that PPS decreases lipopolysaccharide-mediated $\mathrm{NF} \kappa \mathrm{B}$ activation, suppresses leukocyte elastase and inhibits complement activity. ${ }^{15-17}$ As PPS has been found to substantially decrease tubulointerstitial inflammation and preserve renal function in $5 / 6$ nephrectomized rats, ${ }^{18}$ we asked if the antiinflammatory effect of PPS reduced DN in aging mice, which develop severe nephropathy, including typical tubulointerstitial inflammatory lesions. We also tested the effect of PPS on high glucose, AGEs and TNF- $\alpha$-stimulated inflammation in renal cells in vitro.

\section{SUBJECTS AND METHODS Animals}

Seventeen-month-old female C57B6 mice were obtained from National Institute on Aging and were injected with low dose of streptozotocin $(50 \mu \mathrm{g} / \mathrm{g})$ every 3 days for a total of 5-8 injection to induce diabetes (http://www.diacomp.org/ shared/protocols.aspx?model=5). ${ }^{19}$ Mice with stable hyperglycemia $(\geq 250 \mathrm{mg} / \mathrm{dl})$ at 18 months of age were selected for the study. Eighteen-month-old diabetic mice were randomly divided into PPS-treated ( $n=10$, PPS $25 \mathrm{mg} / \mathrm{kg} /$ day in the drinking water) and control $(n=11)$ groups. This dosage of PPS was selected based on previous reports. ${ }^{18}$ The $\mathrm{pH}$ of drinking water with or without PPS remains at 7 . Diabetic mice were followed for 4 months without insulin treatment. Mouse was housed individually and water intake was recorded every other day. Body weight and blood glucose levels were monitored weekly. Additionally, urine ketones were examined. Urine albumin excretion was measured bi-weekly as previously described. ${ }^{20}$ Urine creatinine levels were measured in the same samples and the urine albumin excretion rate was expressed as the ratio of albumin to creatinine. Serum creatinine levels were examined at killing. High-performance liquid chromatography was applied for determining serum creatinine levels using the method described by Yuen et al. ${ }^{21}$

\section{Renal Histology and Morphometry}

Mice were killed 4 months after diabetes. The kidneys were perfused with PBS solution and subsequently one kidney was perfusion-fixed in situ with $4 \%$ paraformaldehyde..$^{20}$ The tissues were embedded in glycol methacrylate or low melting paraffin, and stained with periodic acid Schiff (PAS) and Masson's Trichrome. Tissues were also post-fixed for $1 \mathrm{~h}$ in $1.0 \%$ osmium tetroxide, prestained in $1.25 \%$ uranyl acetate for $1 \mathrm{~h}$, dehydrated through a series of graded alcohol solutions and embedded in EPON epoxy resin for electron microscopy. The glomerular volume and mesangial area were determined by examining PAS sections using a digitizing tablet and video camera. ${ }^{19,20}$ The relative mesangial area was expressed as mesangial/glomerular surface area. Glomerular cell number was determined by counting the nuclear number in at least 30 glomeruli of each section. The glomerular basement membrane thickness was measured by the orthogonal intercept method on electron microscopic images. To determine the number of glomerular fenestrae, the length of fenestrated or unfenestrated glomerular capillary endothelial cytoplasm was measured. Fenestrated endothelial cell cytoplasm was generally thin whereas the thickness of the unfenestrated endothelial cell cytoplasm was twice or more increased. $^{22}$ Tubulointerstitial lesions were scored from 0 to 4 ( 0 , no changes; $1+$, changes affecting $<25 \%$ of the area; $2+$, changes affecting $25-50 \%$ of the area; $3+$, changes affecting $50-75 \%$ of the area; $4+$, changes affecting $75-100 \%$ of the area) based on tubular atrophy, increase in the thickness of basement membranes and interstitial area, and clusters of inflammatory cells. ${ }^{23}$

\section{Immunohistochemistry}

Paraffin sections from diabetic and PPS-treated mice were deparaffinized before staining for inflammation makers, such as macrophages (F4/80, Caltag Laboratories, Burlingame, CA, USA) and phosphorylated NF- $\kappa$ B (p65 (Ser276), Cell Signaling Technology, Inc., Danvers, MA, USA). Additionally, staining for albumin was performed (rabbit anti-mouse albumin, Bethyl Labs, Montgomery, TX, USA). In brief, sections were soaked three times in xylene and passed serially through decreasing concentrations of alcohol. Endogenous peroxidase activity was quenched with $3 \%$ hydrogen peroxide. Antigen unmasking was performed either by putting sections in $0.1 \%$ Triton X-100 for 30 min (for F4/80 staining) or heating sections in citrate buffer for $15 \mathrm{~min}$ in a microwave oven (for phosphorylated NF- $\kappa$ B staining). After incubating with primary antibody at $4{ }^{\circ} \mathrm{C}$ overnight, sections were reacted with biotin-labeled secondary antibody in the Vector VECTASTAIN Elite ABC Kit (Vector Laboratories). Positive staining was revealed with Vector DAB Substrate Kit (SK-4100, Vector Laboratories). Nuclei were counter-stained with hematoxylin in some of sections (Millipore, Billerica, MA, USA). Stained sections were examined under light microscope (Zeiss Axioskop, Germany). The area in renal cortex was digitized under $\times 10$ objective low power with a Sony 3CCD color video camera and a meta imaging series software (Molecular Devices, Downingtown, PA, USA). ${ }^{24}$ Positively stained area of monocyte/macrophages was measured and expressed as the percentage of total cortical area. ${ }^{24}$ The intensity of the staining of albumin in tubules was assessed using the color differentiation program. NF- $\kappa$ B-positive cells were counted under microscope ( $\times 40$ objective).

\section{Proinflammatory Gene mRNA Levels in Aging Diabetic Kidneys}

Total RNA was isolated from renal cortex using a PureYield RNA Midiprep kit (Promega, Madison, WI, USA). The preparation was free of DNA contamination and $500 \mathrm{ng}$ 
of total RNA from each sample was reverse-transcribed as previously described. ${ }^{19,20}$ The levels of MCP-1 (monocyte chemoattractant protein-1), CXCL1 (c-x-c motif ligand 1), RANTES (regulated on activation, normal T-cell expressed and secreted) and IL-6 (interleukin 6) mRNA were determined by real-time polymerase chain reaction used the primers as previously described. ${ }^{24}$ mRNA levels were corrected by the levels of $\beta$-actin or GAPDH mRNA in the same sample. The expression of TNF $\alpha$ mRNA in kidney was determined by both a real-time and a regular PCR using the primer of forward, 5'-GCGACGTGGAACTGGCAGAAG-3', reverse, $5^{\prime}$-GGTACAACCCATCGGCTGGCA-3'. GAPDH and $\beta$-actin mRNA levels were determined at the same time.

\section{Effect of PPS on TNF $\alpha$-Stimulated Upregulation of Proinflammatory Genes in a Proximal Tubular Cell Line}

As $\mathrm{TNF} \alpha$ has an important role in renal inflammation and proximal tubular cells are important target for $\mathrm{TNF} \alpha$ action, we examined the effect of PPS on TNF $\alpha$-stimulated inflammation in proximal tubular cells under normal glucose condition. A proximal tubular cell line obtained from mice transgenic for SV40 $\mathrm{T}$ antigen was kindly provided by Dr. Neilson. ${ }^{25}$ In all, $1 \times 10^{5}$ cells were seeded in each well of a six-well plate. After placing the cells in $0.1 \%$ FBS medium for $24 \mathrm{~h}$, cells were pretreated with PPS $(200 \mu \mathrm{g} / \mathrm{ml})$ for $1 \mathrm{~h}$ before the addition of TNF $\alpha(10 \mathrm{ng} / \mathrm{ml})$. This dosage of PPS was selected based on the calculation that a likely drug concentration achieved from oral absorption of $6 \%$ of given $100 \mathrm{mg} / \mathrm{kg}$ of PPS in rats. ${ }^{18}$ Total RNA was collected from cells $4 \mathrm{~h}$ after the treatment. MCP-1, RANTES, CXCL1, MIP-2 (macrophage inflammatory protein 2), ICAM-1 (intracellular adhesion molecule 1) and iNOS (inducible nitric oxide synthase) mRNA levels were determined $4 \mathrm{~h}$ later by real-time PCR. $\beta$-Actin mRNA levels served as an internal control. The primers used for the measurement were MIP2, forward, 5'-TCCAGAGCTTGAGTGTGACG-3'; reverse, 5'-T TCAGGGTCAAGGCAAACTT- ${ }^{\prime}$; ICAM-1, forward, $5^{\prime}$-TGC TGCAGATGCTGTGAGAGT- ${ }^{\prime}$; reverse, 5' ${ }^{\prime}$-AAACCCTCGAC CCATGTGATC- $3^{\prime}$; and iNOS, forward, $5^{\prime}$-GAAGAAAACCC CTTGTGCTG- ${ }^{\prime}$; reverse, $5^{\prime}$-CTGTGCTGTCCCAGTGAGG-3' Some of cells were treated with TNF $\alpha$ in the presence or absence of PPS for $24 \mathrm{~h}$. The amount of MCP-1 or RANTES production by the cells was measured by ELISA with kits from Invitrogen Corporation (Carlsbad, CA, USA).

\section{Effect of PPS on TNF $\alpha$-Stimulated NF- $\kappa$ B Activation in a Proximal Tubular Cell Line}

The activation of NF- $\kappa \mathrm{B}$ and mitogen-activated protein kinases including p38, JNK (Jun N-terminal kinase) and ERK (extracellular signal-regulated kinase) pathways have an essential role in proinflammatory actions of TNF $\alpha$. Thus, we examined the effect of PPS on the phosphorylation of $\mathrm{I} \kappa \mathrm{B}$, ERK, p38 and JNK by TNF $\alpha$. Proximal tubular cells were allowed to grow to $70 \%$ confluency in $60 \mathrm{~mm}^{2}$ Petri-dish. Cell lysates were collected before or 15, 30, 60 and $120 \mathrm{~min}$ after TNF $\alpha$ treatment $(10 \mathrm{ng} / \mathrm{ml})$. Cells in some dishes were pre-incubated with PPS $(400 \mu \mathrm{g} / \mathrm{ml})$ for $1 / 2 \mathrm{~h}$ before exposure to $\mathrm{TNF} \alpha$. The levels of phosphorylated $\mathrm{I} \kappa \mathrm{B}, \mathrm{ERK}, \mathrm{p} 38$ and JNK were determined by western blots. Briefly, samples containing equal amounts of protein (10-20 $\mu \mathrm{g}$ per lane) were loaded onto SDS-PAGE gels. After electrophoresis, proteins were transferred to PVDF membranes and blotted with antibody against phosphorylated $\mathrm{I} \kappa \mathrm{B}, \mathrm{ERK}, \mathrm{p} 38$ or JNK (Cell Signaling, Boston, MA). After the first analysis, the membranes were stripped to re-probe with antibody against total $\mathrm{I} \kappa \mathrm{B}, \mathrm{ERK}, \mathrm{p} 38$ or JNK, and finally with antibody against $\beta$-actin (Cell Signaling).

To further determine the effect of PPS on NF- $\kappa \mathrm{B}$ transcription activity, proximal tubular cells were transfected with a NF- $\kappa \mathrm{B}$ reporter in the presence or absence of PPS $(50-200 \mu \mathrm{g} / \mathrm{ml})$ and $\mathrm{TNF} \alpha(10 \mathrm{ng} / \mathrm{ml})$. Cells were also transfected with a cDNA expression vector containing constitutively active I $\kappa \mathrm{B}$, dominant-negative IKK or IKK. A $\beta$-galactosidase cDNA expression vector was co-transfected with the NF- $\kappa \mathrm{B}$ reporter to serve as an internal control for transfection efficiency. Luciferase and $\beta$-galactosidase activity were measured using substrate assays as previously described. ${ }^{26}$ The same amount of DNA ( $1 \mu \mathrm{g}$ per well of 24 -well plates) was used for each transfection throughout the experiments.

Additionally, NF- $\kappa \mathrm{B}$ DNA binding was examined by electrophoretic mobility shift assay (EMSA), as previously described. $^{27}$ Briefly, proximal tubular cells were preincubated with or without PPS $(800 \mu \mathrm{g} / \mathrm{ml})$ for $1 / 2 \mathrm{~h}$ before the addition of TNF $\alpha(10 \mathrm{ng} / \mathrm{ml})$. Nuclear protein was extracted from cells $1 \mathrm{~h}$ after treatment. A NF- $\kappa$ B probe (5'-AGTTG AGGGGACTTTCCCAGGC-3') was prepared by annealing complementary single-stranded oligonucleotides with $5^{\prime}$-AC TG- $3^{\prime}$ overhangs (MWG Biotechnologies, Inc.) and was labeled by filling in with $\left[{ }^{32} \mathrm{P}\right] \mathrm{dGTP}$ and $\left[{ }^{32} \mathrm{P}\right] \mathrm{dCTP}$ using Klenow enzyme. Labeled probes were purified with Nuctrap purification columns (Roche Applied Science). EMSAs were performed using $10^{5}$ c.p.m. of labeled probe and $10 \mu \mathrm{g}$ of nuclear extracts per reaction. Supershift with an anti-p50 antibody was also performed. DNA-binding complexes were separated by electrophoresis on a $5 \%$ polyacrylamide-Tris/ glycine-EDTA gel, which was dried and exposed to X-ray film.

\section{Effect of PPS on TNF $\alpha$-Induced Increase in Albumin Permeability in Podocytes}

In all, $1 \times 10^{5}$ podocytes ${ }^{28}$ were seeded onto collagen-coated Transwell filters $(0.4 \mu \mathrm{M}$ pore-size, Corning, New York, NY, USA) placed in the top chamber of each well of a 24 -well plate. After confluence was reached, some wells were treated with TNF $\alpha(20 \mathrm{ng} / \mathrm{ml})$, PPS $(400 \mu \mathrm{g} / \mathrm{ml})$ or PPS plus TNF $\alpha$ in $2 \%$ FBS normal glucose medium for $8 \mathrm{~h}$. Then the medium from both the top and bottom chamber was completely removed, cells were washed twice with PBS and the top chamber was refilled with $0.2 \mathrm{ml} 2 \%$ FBS medium supplemented with $0.5 \mathrm{mg} / \mathrm{ml}$ FITC-labeled bovine serum albumin 
(BSA) (Sigma Aldrich, St Louis, MI, USA), while the bottom chamber was refilled with $0.6 \mathrm{ml} 2 \%$ FBS medium supplemented with $0.5 \mathrm{mg} / \mathrm{ml}$ unlabeled BSA. At different time points, $100 \mu \mathrm{l}$ aliquots were collected from the bottom chamber and fluorescence was measured by a fluorescence spectrophotometer ( $485 \mathrm{~nm}$ excitation, $535 \mathrm{~nm}$ emission). The concentration of FITC-BSA passing through the monolayer was determined by reference to a set of standard dilutions of FITC-BSA. The value of albumin flux through untreated monolayer was arbitrarily defined as $100 \%$.

\section{Effect of PPS on High Glucose and AGE-Stimulated MCP-1 Production in Podocytes}

A podocyte cell line was used for the experiments. ${ }^{28}$ In all, $1 \times 10^{4}$ cells were seeded in each well of a six-well-plate. Cells were cultured under $30 \mathrm{mM}$ high glucose in the presence or absence of PPS $(200 \mu \mathrm{g} / \mathrm{ml})$ for 3 days. Cells in $6 \mathrm{mM}$ normal glucose were used as control. As AGEs formed from the interaction between high glucose and proteins have been shown to have an important role in high glucose-mediated inflammation, we also tested the effect of PPS on AGEstimulated MCP-1 production in podocytes. Cells were treated with AGEs derived from BSA(AGE-BSA, $200 \mu \mathrm{g} / \mathrm{ml}$ ) with or without PPS $(200 \mu \mathrm{g} / \mathrm{ml})$ for $24 \mathrm{~h}$. Cells treated with BSA served as control. MCP-1 in cell supernatants was determined by ELISA and corrected by cell number. NF- $\kappa \mathrm{B}$ transcription activity was also examined by reporter assay as described above in podocytes treated with AGEs with or without PPS.

\section{Statistical Analysis}

Values were expressed as mean \pm s.d. ANOVA or two-tailed unpaired $t$-test was used to evaluate the differences between the means. Significance was defined as $P<0.05$.

\section{RESULTS}

\section{General}

Body weight was not significantly reduced in old diabetic mice (Table 1). The heart weight/body weight or kidney weight/body weight ratio in old diabetic mice remained

Table 1 General characteristics of diabetic mice

\begin{tabular}{lccc}
\hline & \multicolumn{3}{c}{ Old mice (22 months) } \\
\cline { 2 - 4 } & Control $(n=10)$ & Diabetic $(n=11)$ & PPS $(n=10)$ \\
\hline Body weight (g) & $25.7 \pm 1.4$ & $24.4 \pm 0.5$ & $24.1 \pm 1.3$ \\
Heart weight (mg) & $167 \pm 19$ & $169 \pm 23$ & $170 \pm 14$ \\
Kidney weight (mg) & $218 \pm 11$ & $225 \pm 19$ & $221 \pm 23$ \\
Glucose (mg/dl) & $106 \pm 34$ & $301 \pm 36$ & $332 \pm 68$ \\
Scr (mg/dl) & $0.109 \pm 0.03$ & $0.138 \pm 0.02^{*}$ & $0.118 \pm 0.02$ \\
\end{tabular}

PPS, pentosan polysulfate

${ }^{*} P<0.05$ vs old mice control. similar to their age-matched controls, and PPS treatment did not change these values. There was no significant difference in glycemic levels between PPS-treated and -untreated old diabetic mice. No ketonuria was spotted in both groups of diabetic mice. However, serum creatinine levels were significantly elevated in untreated 22-month-old diabetic mice as compared with age-matched non-diabetic mice $(P<0.05)$ (Table 1). PPS treatment prevented the increase in serum creatinine.

\section{Albuminuria}

Old diabetic mice developed progressively severe albuminuria. Urinary albumin excretion was 7 -fold higher after 2 months of diabetes, and continued to increase after 4 months of diabetes, reaching levels which were about 14-fold higher, than in old control mice (Figure 1). The increase in albuminuria was blunted in PPS-treated old diabetic mice, reaching a plateau after 3 months of diabetes, and remained lower than untreated old diabetic mice.

\section{Histopathology}

As previously reported, 22-month-old non-diabetic control mice had increased glomerular size, a slight increase in the mesangial areas, and a largely normal tubulointerstitium ${ }^{20,24}$ (Figures 2 and 3). The superimposition of diabetes resulted in severe glomerular, tubulointerstitial and vascular lesions ${ }^{24}$ (Figures 2 and 3). There was an increase in overall glomerular cell number in old diabetic mice $(49.5 \pm 4.9$ nuclei/glomerulus vs $43.7 \pm 8.5$ nuclei/glomerulus in 22 -month-old controls, $P<0.05)$. The mesangium was diffusely and markedly increased (Figure 2). Morphometric analysis confirmed that mesangial area was significantly enlarged in old diabetic mice compared with 22-month-old controls $(P<0.05)$ (Figure 2). Typical vascular lesions seen in human DN including the

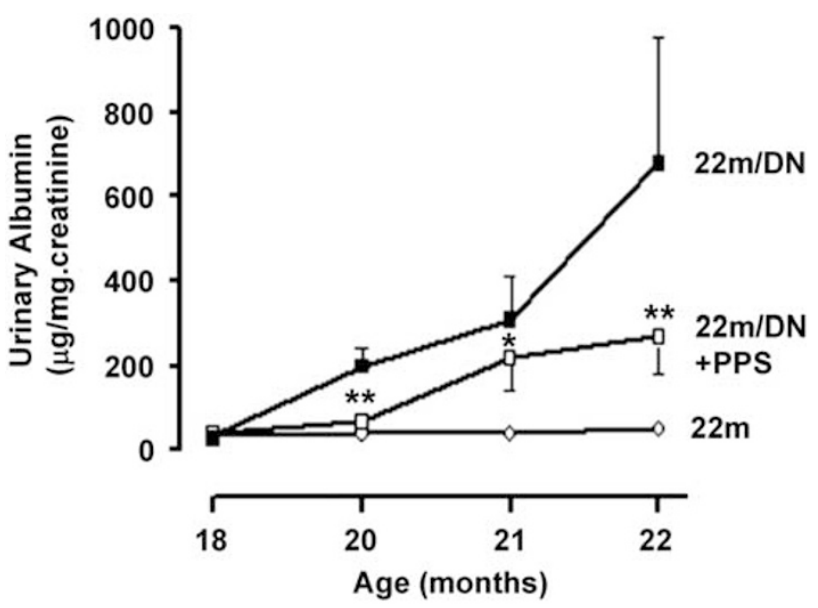

Figure 1 Decreased albuminuria in PPS-treated aging diabetic mice. Twenty-two-month-old diabetic mice developed progressive albuminuria (22 month/DN), which was significantly reduced by PPS treatment. ${ }^{*} P<0.05,{ }^{*} P<0.01$ vs untreated diabetic mice at the same time point. Albuminuria was not present in 22-month-old non-diabetic control mice. 

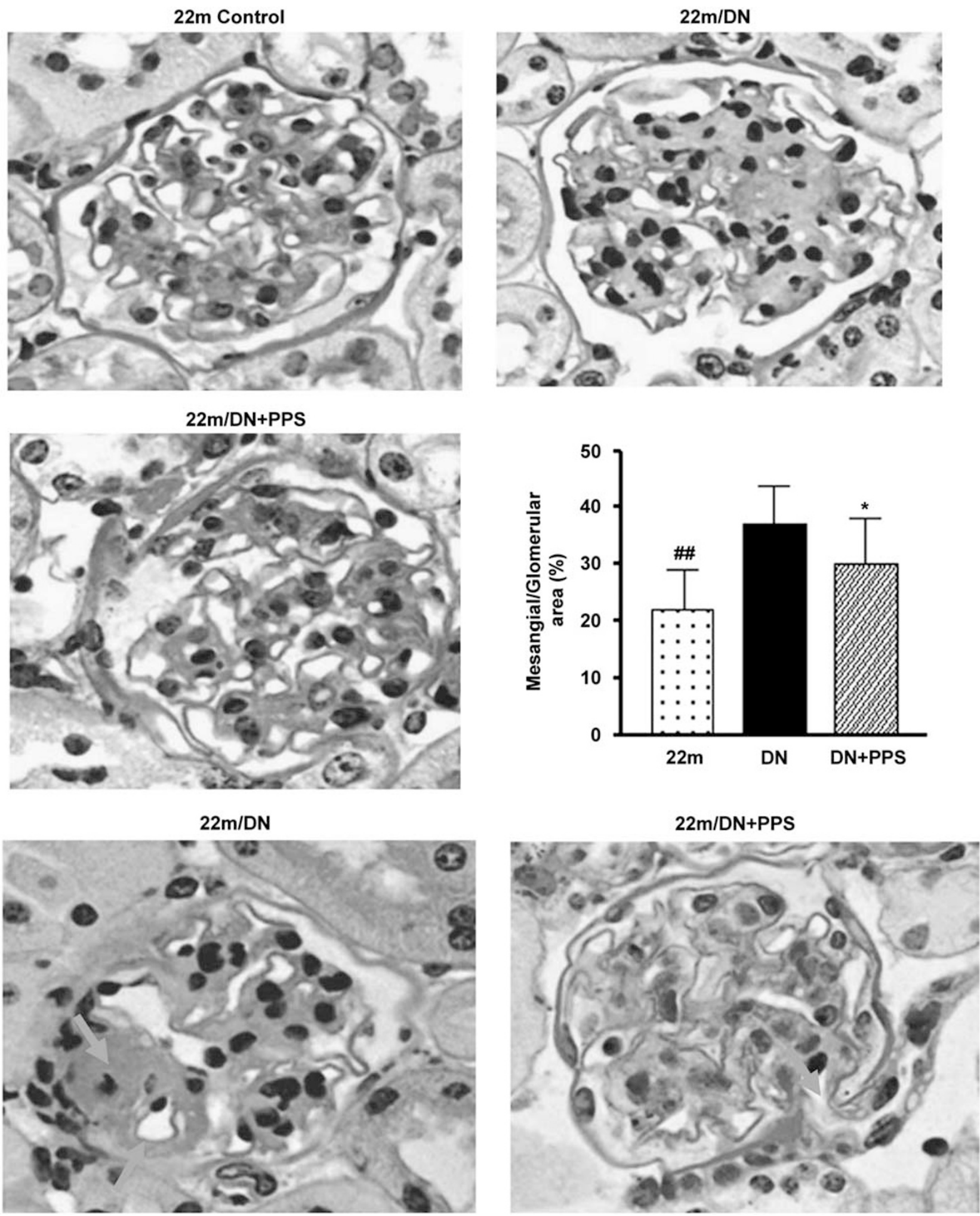

Figure 2 Reduced glomerular lesions in PPS-treated aging diabetic mice. Representative pictures show that compared with 22 months control mouse, mesangial area is enlarged in 22-month-old diabetic mouse $(22$ month/DN, PAS $\times 400)$. Mesangial expansion is reduced in PPS-treated diabetic mouse (22 month/DN + PPS, PAS $\times 400$ ). Morphometry analysis of mesangial area, expressed as a percentage of total glomerular area, was increased in the kidneys of untreated diabetic mice (DN). ${ }^{\# \#} P<0.01$ vs 22 -month controls. PPS treatment decreased mesangial area in diabetic mice. ${ }^{\star} P<0.05$ vs DN. Arteriolar lesions characterized by hyalinosis are present in afferent and efferent arterioles (arrows) of untreated 22-month-old diabetic mouse while the arteriole is virtually normal in PPS-treated mouse (arrow). 
a

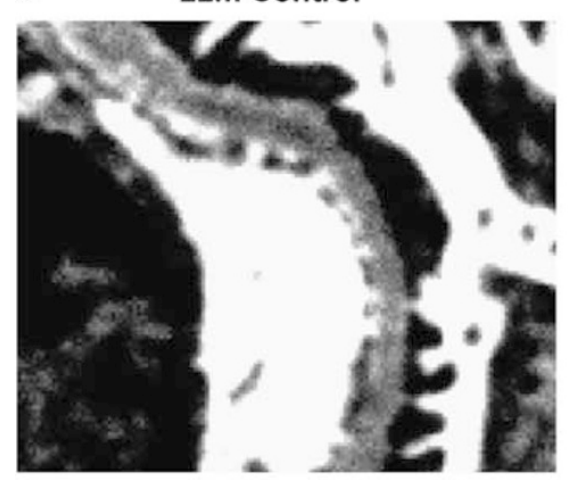

$22 \mathrm{~m} / \mathrm{DN}$

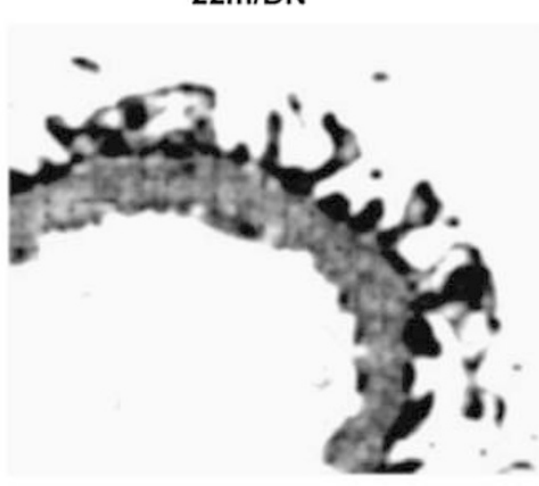

$22 \mathrm{~m} / \mathrm{DN}+\mathrm{PPS}$

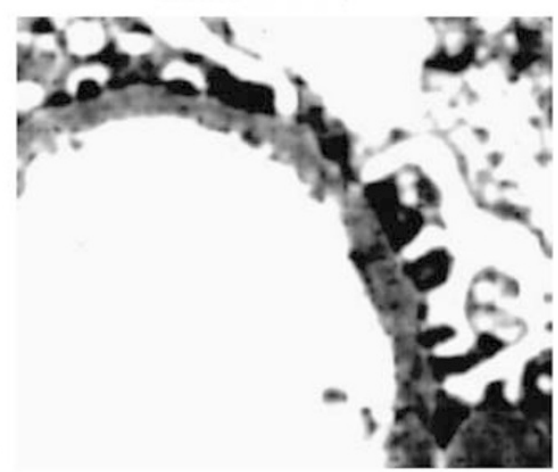

b

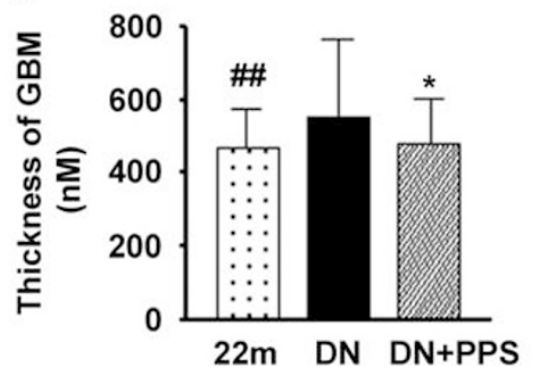

C

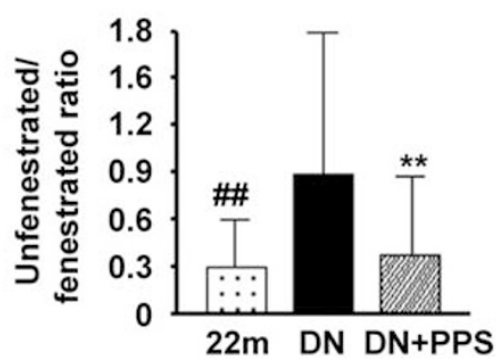

Figure 3 Reduction in the thickness of glomerular basement membranes and increased glomerular endothelial fenestration in PPS-treated aging diabetic mice. (a) The basement membranes are irregularly thickened and there is fusion of foot processes in 22 -month-old diabetic mice (EM $\times 5000$ ). The thickness of basement membrane is reduced and podocyte foot processes are relatively well preserved in PPS-treated aging diabetic mice. (b) Measurement of the width of the glomerular basement membranes showed increased thickness in untreated 22 -month-old diabetic mice ${ }^{\# \# ~} P<0.01$ vs 22 -month controls). PPS-treatment decreased the thickness. ${ }^{*} P<0.05$ vs untreated aging diabetic mice (DN). (c) Quantitative analysis of glomerular endothelial cell fenestration. Data are expressed as the ratio of unfenestrated to fenestrated glomerular endothelia. The unfenestrated areas were significantly increased in glomeruli of untreated aging diabetic mice. ${ }^{\# \#} P<0.01$ vs 22 -month controls. The unfenestrated areas were reduced by PPS treatment. ${ }^{*} P<0.01$ vs untreated aging diabetic mice (DN). The glomerular basement membranes are relatively normal in 22 -month-old control mouse $(E M \times 5000)$.

increase in thickness of arteriolar wall and hyaline deposition in afferent and efferent arterioles were present in old diabetic mice (Figure 2). The glomerular basement membranes were generally thickened in old diabetic mice, with some areas of marked increase in width by electron microscopy (Figure 3). Effacement of podocyte foot processes was present in some peripheral loops and the number of glomerular capillary endothelial cells in fenestrae was significantly decreased in old diabetic mice $(P<0.05)$ (Figure 3$)$. There was diffuse tubular atrophy, interstitial fibrosis and inflammatory cell infiltrate in old diabetic mice $(P<0.01)$ (Figure 4).

The kidney lesions were significantly improved by PPS treatment. The expansion of mesangial areas was reduced $(P<0.05)$ (Figure 2). The number of glomerular cells was decreased $(42.8 \pm 12.3$ vs $49.5 \pm 4.9$ nuclei/glomerulus in untreated diabetic mice $)(P<0.01)$. In addition, the thickness of basement membranes and the loss of glomerular endothelial fenestrations were decreased by PPS-treatment (Figure 3). There were no hyalinosis and obvious vascular wall lesions in PPS-treated old diabetic kidneys (Figure 2). Importantly, PPS treatment nearly completely prevented the development of tubulointerstitial lesions in old diabetic mice
$(P<0.01)$ (Figure 4). As tubules are actively involved in albumin retrieval and degradation, tubular injury has been suggested to have a role in albuminuria. ${ }^{29-31}$ Thus, we examined albumin staining in kidneys from old controls and old diabetic mice treated with or without PPS. Albuminpositive staining was present in some of glomerular parietal epithelial and tubular cells in old control mice (Figure 5). A prominent increase in staining intensity in tubules was found in old diabetic mice. Digital quantitation of the intensity of immunostaining supported the visual impression of increased tubular albumin staining in old diabetic kidneys. PPS treatment largely prevented the increase (Figure 5).

\section{PPS Treatment Decreased Macrophage Infiltrates in the Kidneys of Old Diabetic Mice}

Kidney sections were stained with an anti-F4/80, a macrophage marker, to characterize the inflammatory lesions. Macrophages were rarely seen in the kidneys of control old mice (Figure 6a). There was an extensive infiltrate of macrophages and it was common to see macrophage cluster in untreated kidneys of old diabetic mice (Figure 6b). Direct measurement of macrophage positively stained area showed 
$22 \mathrm{~m}$ Control

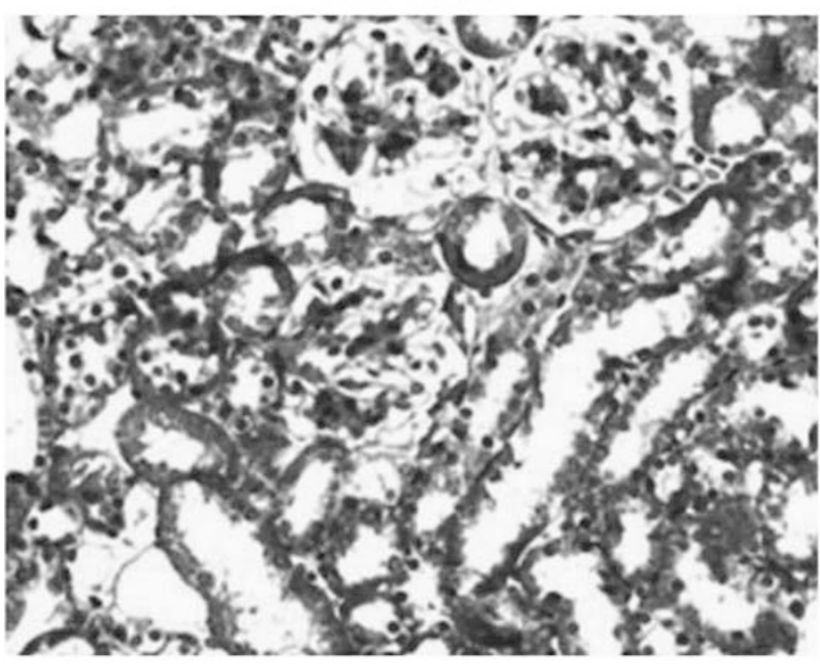

$22 \mathrm{~m} / \mathrm{DN}$

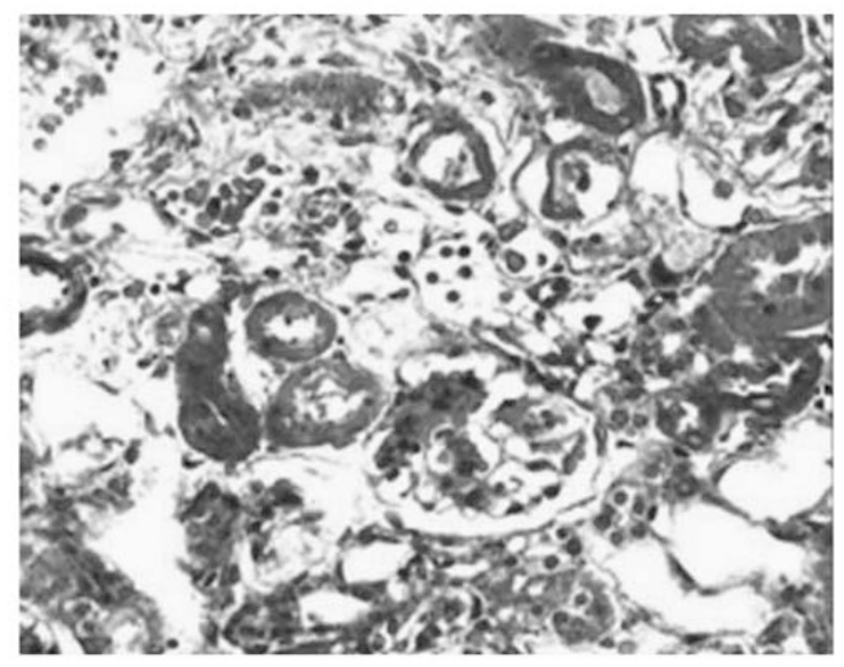

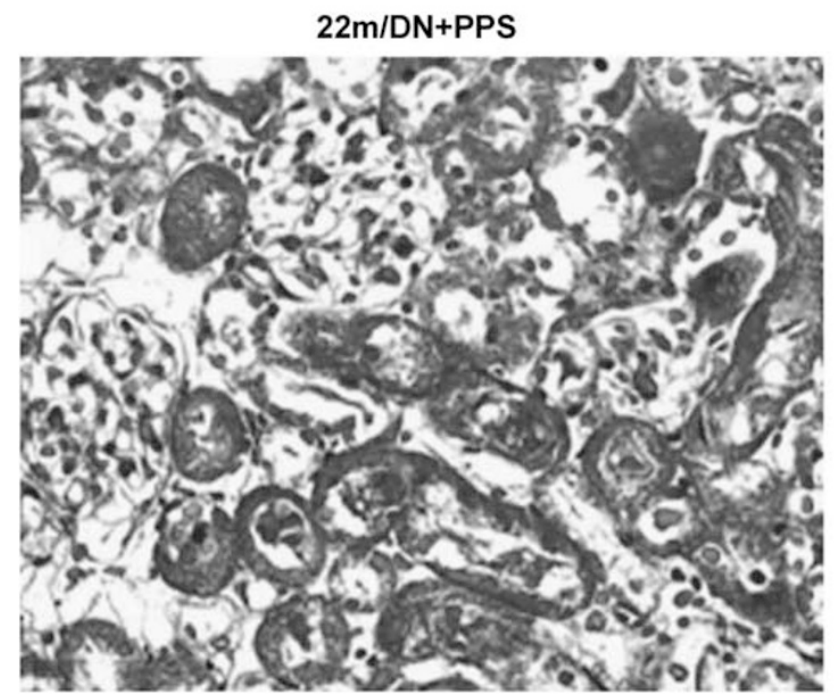

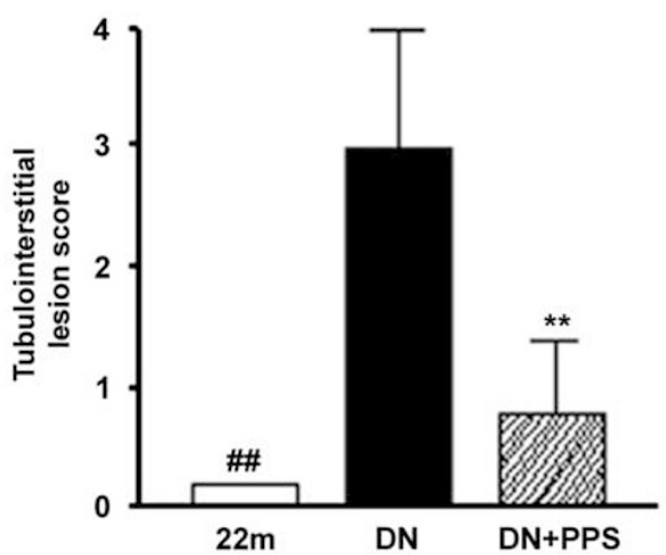

Figure 4 Prevention of tubulointerstitial lesions by PPS treatment in aging diabetic mice. Although tubulointerstitium is largely normal in 22 months control mice, untreated 22-month-old aging diabetic mice have severe tubulointerstitial lesions including extensive inflammatory cell infiltration and diffuse tubular atrophy and interstitial fibrosis (blue staining of matrix), representative Masson's trichrome stains (22 month/DN, $200 \times$ ). The tubulointerstitial lesions were markedly decreased in PPS-treated mice (22 month/DN + PPS), as evidenced by decreased number and size of connective tissue zones (blue staining) and a sharp reduction in the amount of inflammatory cells in the interstitium. The tubulointerstitial lesions in untreated aging diabetic mice (DN), assessed by a semiquantitative measurement was significantly greater than in PPS-treated aging diabetic mice (DN + PPS) $(3+v s 0.8+)$. ${ }^{\# \#} P<0.01$, ${ }^{*} P<0.01$ vs untreated aging diabetic mice. The tubules and interstitium in kidneys from 22-month-old non-diabetic control mice were essentially normal.

that about $10 \%$ of tubulointerstitium in untreated old diabetic mice was occupied by macrophages (Figure 6). The number of infiltrating macrophages was substantially reduced after PPS treatment (Figure $6 \mathrm{c}$ ). Although nuclear phosphorylated NF- $\kappa \mathrm{B}$ p 65 staining, an indication of NF- $\kappa \mathrm{B}$ activation, was present in interstitial capillary endothelial cells, parietal epithelial cells, and some cells of distal tubules and collecting ducts in the kidneys of 22-month-old nondiabetic mice ${ }^{24}$ (Figure $6 \mathrm{~d}$ ), the number of NF- $\kappa \mathrm{B}$-positive cells was markedly increased in the glomeruli and tubulointerstitium of untreated old diabetic mice $(41 \pm 21$ cells per field vs $16 \pm 9$ cells per field in old controls, $P<0.01$,
Figure 6). This number was sharply decreased by PPS treatment (Figure 6).

There was a significant increase in mRNA levels of MCP-1, RANTES and CXCL-1 in the kidneys of untreated old diabetic mice (Figures $7 \mathrm{a}-\mathrm{c}$ ), but PPS treatment decreased the upregulation of these chemokines $(P<0.01)$. The expression of IL- 6 and TNF $\alpha$, two cytokines that are closely associated with chronic inflammation in aging and have an active role in inflammation were examined to explore their role in the kidneys of old diabetic mice. IL-6 mRNA levels were similar between the kidneys of old diabetic and control mice (Figure 7d), and PPS treatment did not affect the levels. 

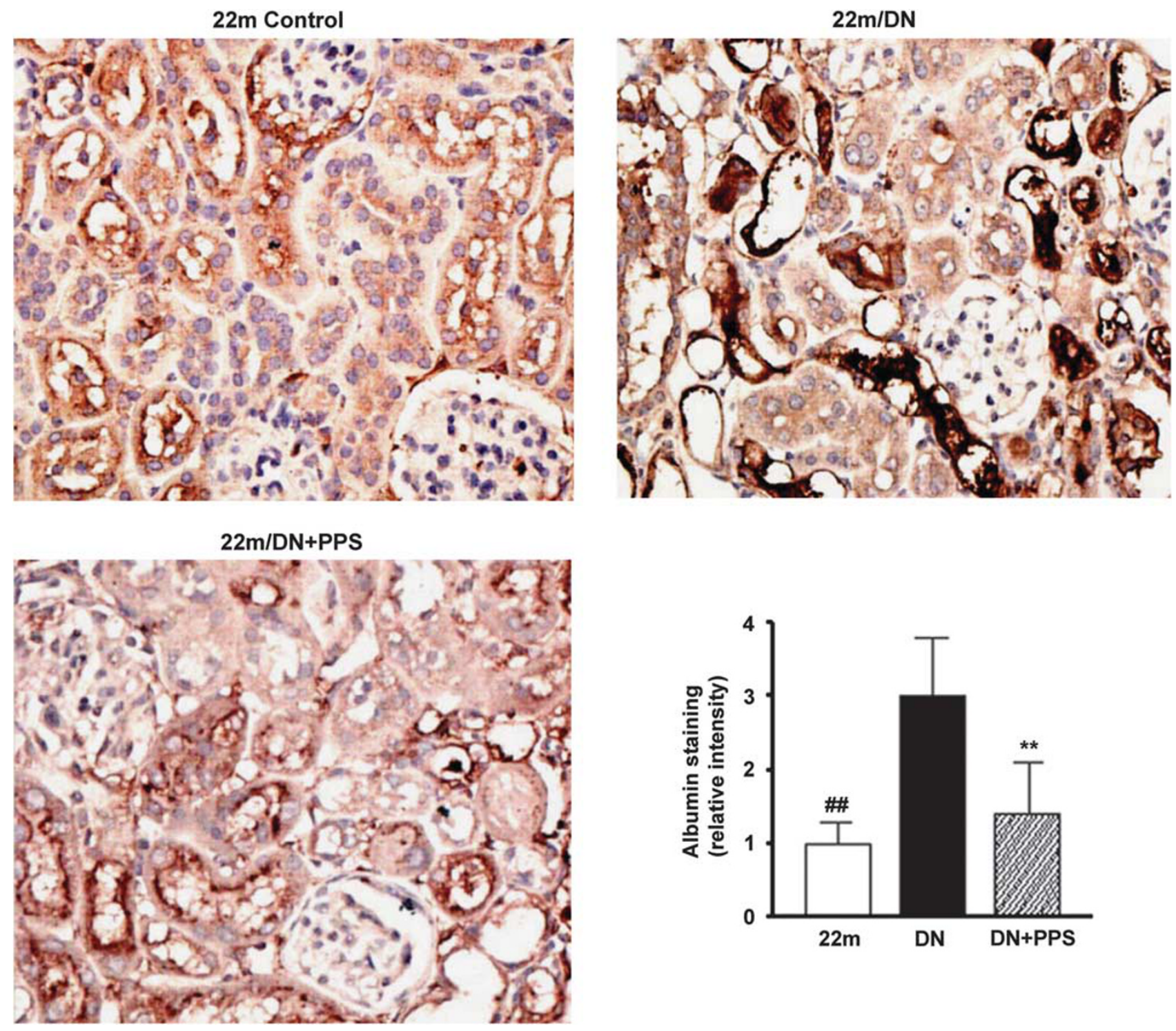

Figure $5 \mathrm{Immunostaining} \mathrm{for} \mathrm{albumin.} \mathrm{Positive} \mathrm{staining} \mathrm{for} \mathrm{albumin} \mathrm{is} \mathrm{seen} \mathrm{in} \mathrm{parietal} \mathrm{epithelial} \mathrm{cells} \mathrm{of} \mathrm{glomerulus} \mathrm{and} \mathrm{some} \mathrm{tubules} \mathrm{of} 22$ months control mice. There is a visible increase in albumin staining intensity in tubules of untreated aging diabetic mice. Albumin staining in tubules of PPS-treated aging diabetic mice is similar to that in old controls. The intensity of albumin staining was measured by a morphometry software and defined by an arbitrarily unit. ${ }^{\# \#} P<0.01,{ }^{*} P<0.01$ vs untreated aging diabetic mice.

Although TNF $\alpha$ mRNA was not expressed in 22-month-old control kidneys, it was present in untreated old diabetic kidneys $^{24}$ (Figure 6e). The expression of TNF $\alpha$ mRNA was not demonstrable in the kidneys of old diabetic mice treated with PPS (Figure 6e). Moreover, the levels of MCP-1, RANTES and CXCL-1 mRNA were decreased in PPS-treated old diabetic mice, coincident with the reduction of infiltrating macrophages, lower levels of NF- $\kappa \mathrm{B}$ activation and the absence of TNF $\alpha$ expression (Figures 6 and 7).

\section{Inhibition of TNF $\alpha$ Action by PPS via Suppression of NF- $\boldsymbol{k B}$}

To determine whether PPS directly affected the proinflammatory action of $\mathrm{TNF} \alpha$, proximal tubular cells were pretreated with PPS before exposure to TNF $\alpha$. PPS largely blocked TNF $\alpha$-induced upregulation of MCP-1, RANTES, MIP-2, ICAM-1 and iNOS in proximal tubular cells (Figures $7 \mathrm{f}-\mathrm{m})$. As both the NF- $\kappa \mathrm{B}$ and MAPKs pathways are critically involved in proinflammatory action of TNF $\alpha$, we examined the effect of PPS on NF- $\kappa$ B and MAPK activation after $\mathrm{TNF} \alpha$-stimulation. Phosphorylated $\mathrm{I} \kappa \mathrm{B}$ levels were increased at $30 \mathrm{~min}$ in proximal tubular cells after TNF $\alpha$ stimulation and remained high after $2 \mathrm{~h}$ (Figure 8a). When cells were treated with PPS before TNF $\alpha$-stimulation, the levels of I $\kappa$ B phosphorylation were decreased $40-60 \%$. However, the levels of total $\mathrm{I} \kappa \mathrm{B}$ seem to be stable in proximal tubular cells even after TNF $\alpha$ stimulation. Thus, we further assessed NF- $\kappa \mathrm{B}$ transcription activity. The NF- $\kappa \mathrm{B}$ luciferase reporter assay 

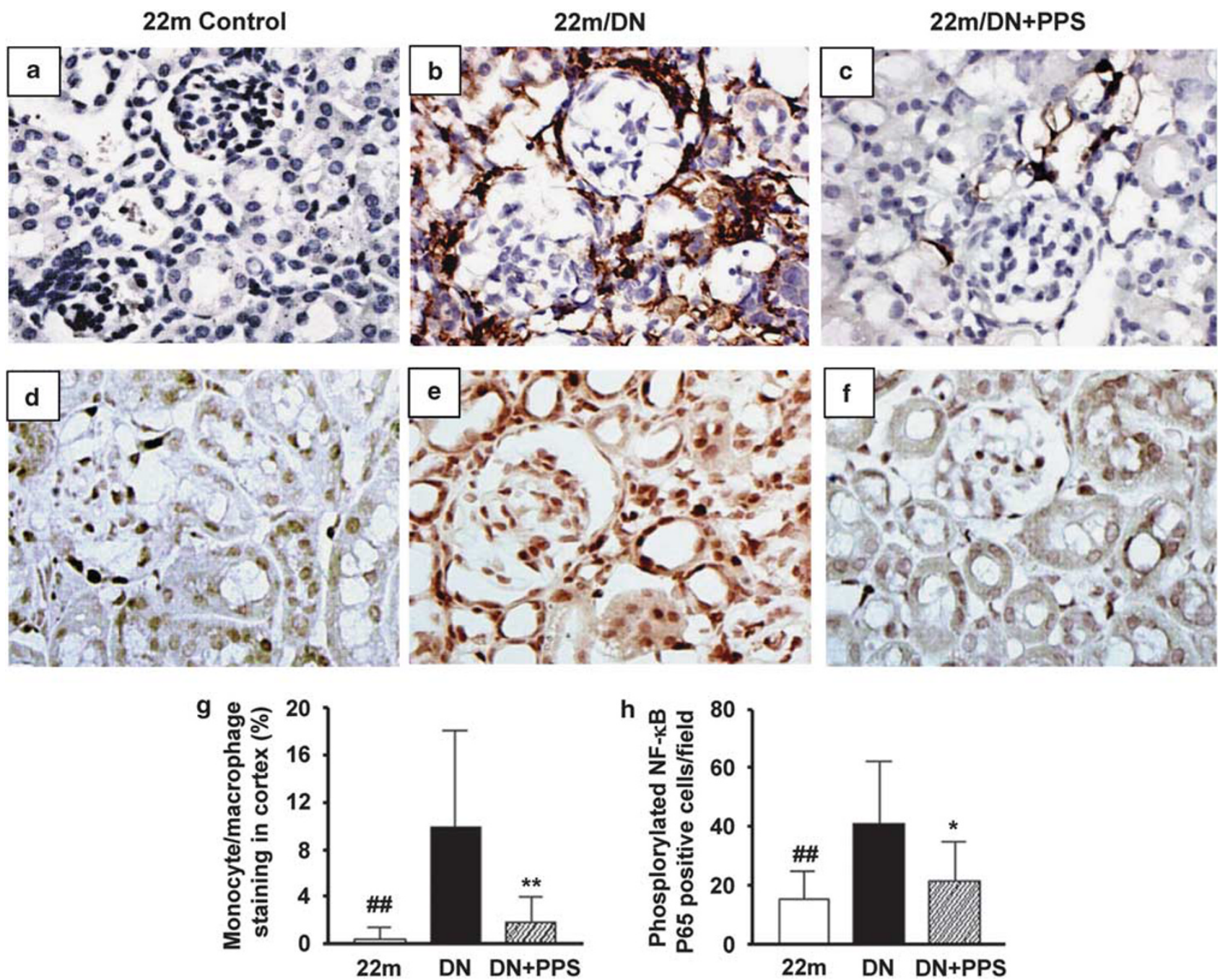

Figure 6 Immunostaining for monocyte/macrophage and NF- $\kappa$ B. The presence of macrophages was assessed by F4/80 staining. Positive staining is rarely found in 22-month-old control mice (a). Diffuse and multi-focal areas of macrophage infiltration are present in the tubulointerstitium of 22-month aging diabetic mice (22 month/DN, b). The number of macrophages was substantially reduced in PPS-treated mice (22 month/DN + PPS, c). Some nuclei in glomerular parietal epithelials and in glomerulus are stained positively for phosphorylated NF- $\kappa$ B (p65) (Ser276), a marker of NF- $\kappa$ B activation $(\times 500, \mathbf{d})$. A prominent increase in NF- $\kappa$ B-positive cells is seen in the glomerulus, tubules and interstitium of aging diabetic mice (e). The number of nuclei staining positively for NF- $\kappa$ B positive is noticeably decreased in PPS-treated aging diabetic mice (f). Quantitative measurement of area occupied by monocytes/macrophages shows that an average of $10 \%$ renal cortex in aging diabetic mice are these cells $(\mathbf{g}) .{ }^{\# \#} P<0.01,{ }^{* *} P<0.01$ vs untreated aging diabetic mice (DN). (h) The number of NF- $\kappa$ B-positive nuclei was counted in sections from 22-month control, aging diabetic and PPS-treated aging diabetic mice. ${ }^{\# \#} P<0.01,{ }^{*} P<0.05$ vs untreated aging diabetic mice (DN).

showed that PPS treatment dose-dependently decreased $\mathrm{TNF} \alpha$-stimulated NF- $\kappa \mathrm{B}$ transcriptional activity in proximal tubular cells (Figure 8b). Furthermore, PPS treatment nearly completely blocked the TNF $\alpha$-induced increase in NF- $\kappa$ B DNA-binding activity (Figure $8 \mathrm{c}$ ). PPS treatment also suppressed TNF $\alpha$-stimulated ERK1/2 phosphorylation in proximal tubular cells (data not shown).

\section{High Glucose- and AGE-Stimulated MCP-1 Production in Podocytes is Decreased by PPS Treatment}

Since hyperglycemia could either directly increase inflammation, or do so via the formation of AGE, we assessed the levels of MCP-1 in podocytes at baseline and after exposure to high glucose or AGE in the presence or absence of PPS. Although exposure to $30 \mathrm{mM}$ high glucose for 3 days resulted in increased MCP-1 production in podocytes, the increase was abrogated by PPS (Figure 9a). Additionally, podocytes cultured in $6 \mathrm{mM}$ glucose also had decreased MCP-1 production when PPS was added to the medium. As previously reported, AGE stimulation increased MCP-1 production and activated NF- $\kappa \mathrm{B}$ transcription activity in podocytes ${ }^{32}$ (Figures $9 \mathrm{~b}$ and c). Both baseline and AGEstimulated NF- $\kappa \mathrm{B}$ transcription activity and MCP-1 production was suppressed by PPS treatment (Figure 9). 

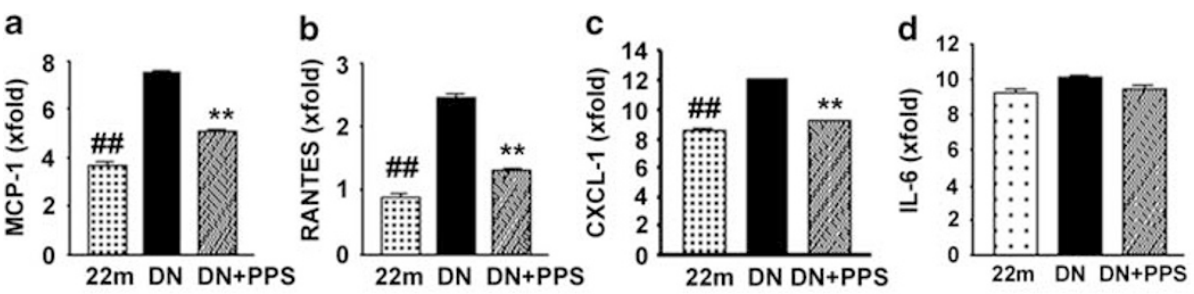

e
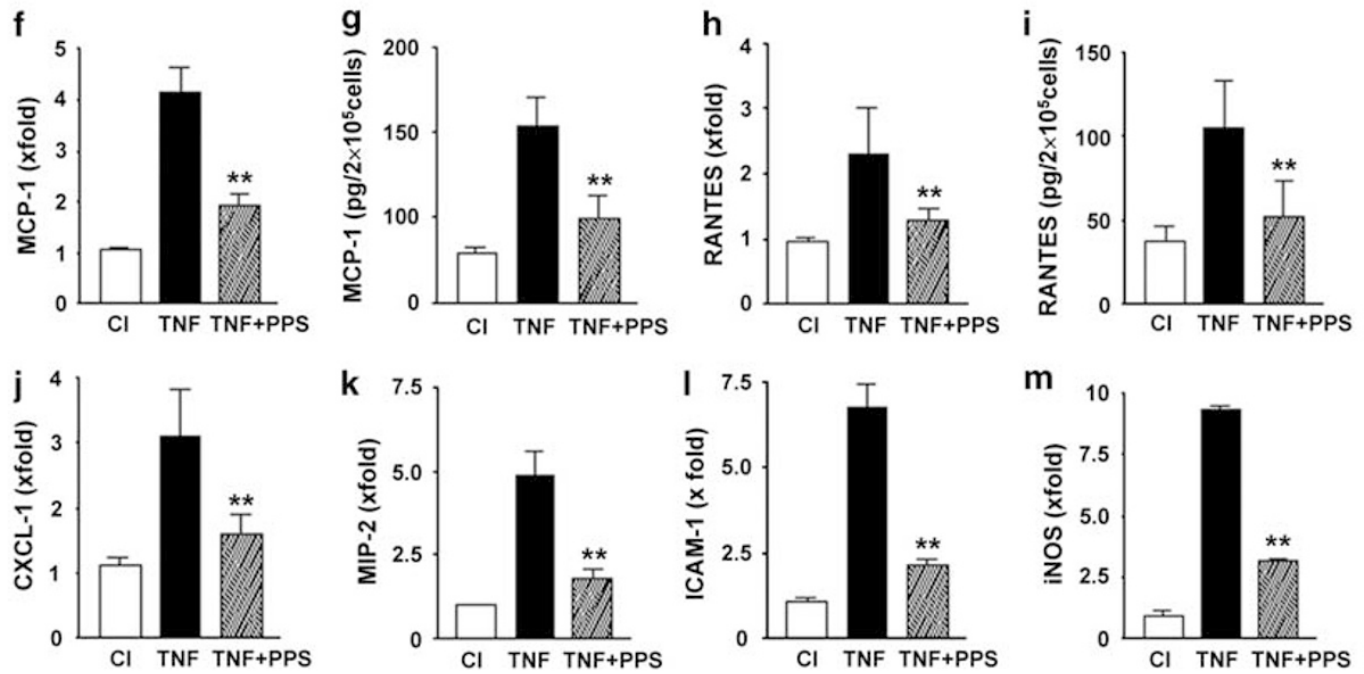

Figure 7 PPS treatment decreased expression of proinflammatory genes. (a-c) MCP-1, RANTES and CXCL-1 mRNA levels were significantly increased in aging diabetic mice, compared with aging control mice. The increase was largely blocked by PPS treatment. The MCP-1, RANTES and CXCL-1 mRNA levels in 22-month-old control (22 month) and 22-month-old diabetic mice treated without (DN) and with PPS (DN + PPS) were determined by real-time PCR and were corrected by $\beta$-actin mRNA levels in the same sample. ${ }^{*} P<0.01$ vs untreated aging diabetic mice (DN). (d) IL-6 mRNA expression: IL-6 mRNA levels in kidneys were determined by real-time PCR. There was no difference in IL-6 mRNA levels among 22-month-old non-diabetic and aging diabetic mice treated with and without PPS. (e) Representative gels of TNF $\alpha$ and GAPDH mRNA levels of kidneys from 22-month-old, 22-month-old diabetic mice ( 22 month/DN) and 22-month-old diabetic mice treated with PPS (22 month/DN + PPS). TNF $\alpha$ mRNA expression was only found in the kidneys of 22-month-old diabetic (lanes 1-3). The expression was absent in 22-month-old (lane 7) and PPS-treated 22-month-old diabetic mice (lanes 4-6) even when PCR cycles were increased to 40. CDNA obtained from mouse macrophages $(\mathrm{M} \varphi)$ was used as a positive control for PCR (data not shown). The levels of GAPDH mRNA were relative similar among the samples. (f-m) PPS decreased TNF $\alpha$-stimulated inflammation in proximal tubular cells. Proximal tubular cells were treated with PPS $(200 \mu \mathrm{g} / \mathrm{ml})$ or with saline for $1 \mathrm{~h}$ before stimulating with TNF $\alpha(10 \mathrm{ng} / \mathrm{ml})$. RNA was collected $4 \mathrm{~h}$ later. The mRNA levels in cells without TNF $\alpha$ stimulation (control) were arbitrarily defined as 1. TNF $\alpha$ treatment caused a 2-9-fold increase in the expression of the following mRNAs: (f) MCP-1, (h) RANTES, (j) CXCL-1, (k) MIP-2, (I) ICAM-1 and (m) iNOS. Pretreatment with PPS largely prevented the increased expression of these mRNAs after TNF $\alpha$ treatment. Furthermore, PPS decreased TNF $\alpha$-stimulated (g) MCP-1 and (i) RANTES protein production by proximal tubular cells. ${ }^{* * P}<0.01$ vs TNF $\alpha$ alone.

\section{TNF $\alpha$-Induced Increased Albumin Permeability in Podocytes In Vitro is Decreased by PPS Treatment}

The amount of FITC-labeled albumin that passed through a monolayer of podocytes was increased by $34 \%$ at $2 \mathrm{~h}$ after $\mathrm{TNF} \alpha$ treatment. This increase was reduced by nearly $60 \%$ in the presence of PPS (Figure 10).

\section{DISCUSSION}

Although the pathogenesis of DN is complex, it is increasingly regarded as an inflammatory disease., ${ }^{73-35}$ This conclusion is largely based on the presence of lymphocyte and macrophage infiltration and overexpression of proinflammatory cytokines and chemokines in kidney at every stage of disease in human. Moreover, inflammation very likely has a role in the progression of $\mathrm{DN}$, because mice lacking MCP-1 or ICAM-1 are resistant to DN. ${ }^{36-39}$ Although several anti-inflammatory drugs have been proposed for the treatment of $\mathrm{DN},{ }^{12,40-42}$ the lack of a DN model with typical inflammatory lesions has hindered their study. We recently established a model of DN in aging mice that mimics DN in humans, ${ }^{24}$ making it possible to address the possibility that the anti-inflammatory properties of PPS might be useful for the treatment of DN. Diabetic aging C57B6 mice develop severe nephropathy with renal insufficiency, progressive albuminuria, and extensive glomerular, vascular and tubulointerstitial lesions. We found that PPS treatment substantially decreased inflammation and the progression of $\mathrm{DN}$ in aging mice.

The inflammatory lesions in aging DN were characterized by extensive macrophage infiltration and upregulation of $\mathrm{TNF} \alpha$, a proinflammatory cytokine, as well as several chemokines (MCP-1, RANTES and CXCL-1). ${ }^{24}$ As TNF $\alpha$ is actively 


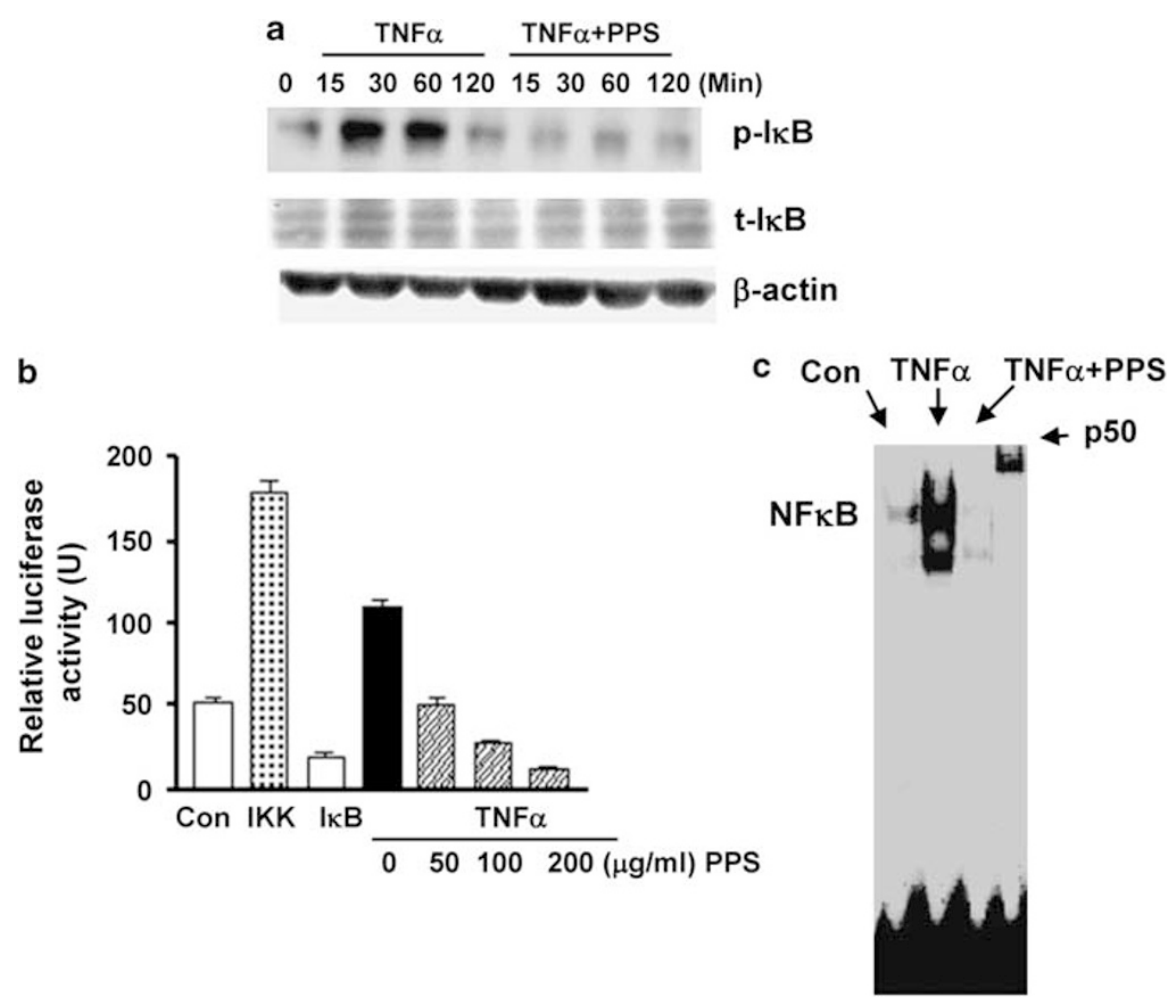

Figure 8 (a) TNF $\alpha$-stimulated NF- $\kappa$ B activation is suppressed by PPS. Proximal tubular cells were pretreated with PPS or saline for 30 min before the addition of TNF $\alpha$. Cellular protein was collected the indicated time points. Phosphorylated $I_{\kappa} \mathrm{B}$, total $\iota_{\kappa} \mathrm{B}$ and $\beta$-actin levels were determined by western blot. The experiments were repeated three times. (b) NF- $\kappa$ B transcription activity was determined by transfecting proximal tubular cells with a luciferase reporter in the presence or absence of an IKK or I $\kappa$ B cDNA. Transfection efficiency was determined by co-transfecting cells with a $\beta$-galactosidase plasmid. Data are expressed as relative units after correcting by the galactosidase activity. Transfected cells were also treated with TNF $\alpha$ in the presence or absence of PPS after transfection. (c) Nuclear protein was isolated from proximal tubular cells $60 \mathrm{~min}$ after treating cells with TNF $\alpha$ in the presence or absence of PPS. The binding of NF- $\kappa$ B protein to DNA was determined by a gel shift assay. Positive controls included macrophages treated with LPS and the presence of anti-p50 antibody in the reaction. NF- $\kappa B$ DNA-binding activity is weakly present in untreated proximal tubular cells (control) and the activity is increased by TNF $\alpha$. TNF $\alpha$-stimulated NF- $\kappa$ B DNA-binding activity is nearly completely blocked by PPS treatment. The presence of p50 antibody visibly reduces the mobility.
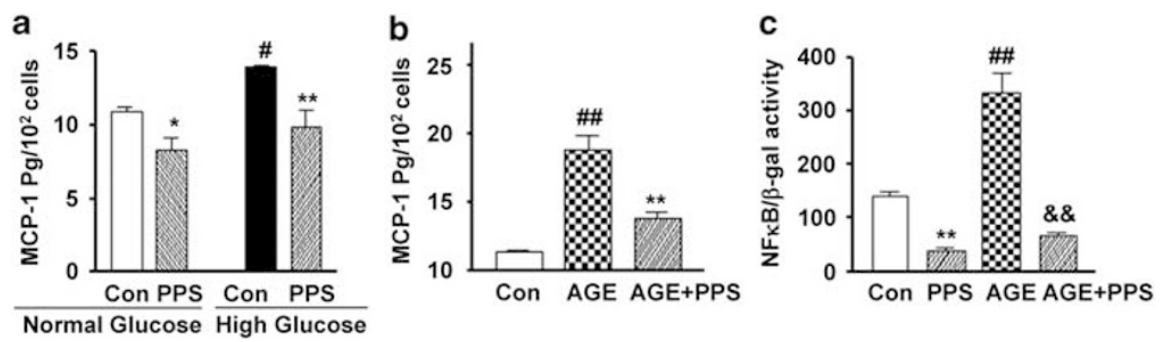

Figure 9 PPS suppressed high glucose and AGE-stimulated inflammation in podocytes. (a) Podocytes were grown in high glucose (25 mM) and normal glucose $(6 \mathrm{mM})$ in the presence or absence of PPS $(200 \mu \mathrm{g} / \mathrm{ml})$ for 3 days. MCP-1 production by the cells was determined. ${ }^{\star} P<0.05 \mathrm{vs}$ control (con); ${ }^{\#} P<0.05$ vs cells cultured in $6 \mathrm{mM}$ glucose; ${ }^{* *} P<0.01$ vs cells cultured in $25 \mathrm{mM}$ glucose. (b) Podocytes were treated with AGE-BSA (200 $\left.\mu \mathrm{g} / \mathrm{ml}\right)$ in the presence or absence of PPS $(200 \mu \mathrm{g} / \mathrm{ml})$ for $24 \mathrm{~h}$. Control (Con) were cells treated with BSA $(200 \mu \mathrm{g} / \mathrm{ml}) .{ }^{\# \#} P<0.01$ vs Control; ${ }^{* * P}<0.01$ vs cells treated only with AGE. (c) PPS decreased AGE-stimulated NF- $\kappa$ B transcription activity. Activity was determined by transfecting podocytes with a luciferase reporter. Cells were treated with AGE $(200 \mu \mathrm{g} / \mathrm{ml})$ in the presence or absence of PPS ( $200 \mu \mathrm{g} / \mathrm{ml})$. Transfection efficiency was determined by co-transfecting cells with a $\beta$-galactosidase plasmid. Data are expressed as relative units after correcting by galactosidase activity. ${ }^{* *} P<0.01,{ }^{\# \#} P<0.01$ vs Control (Con); ${ }^{\&} \&<0.01$ vs cells treated only with AGE.

involved in chronic inflammatory diseases and induces proinflammatory responses in glomerular and tubular cells both in vitro and in vivo, ${ }^{24,43-45}$ the upregulation of TNF $\alpha$ in aging diabetic kidney may contribute to the inflammatory lesions. In this study, we found that PPS suppresses TNF $\alpha$ expression and TNF $\alpha$-mediated inflammation. Renal TNF $\alpha$ 


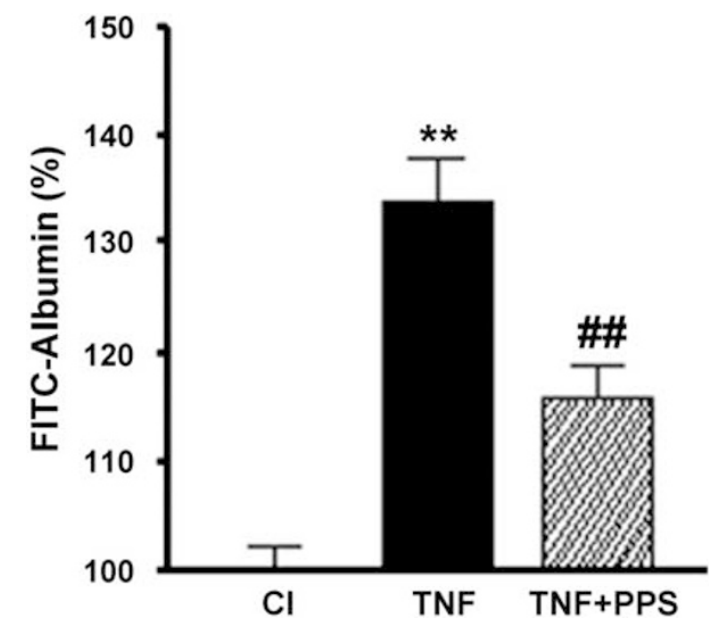

Figure 10 PPS decreases TNF $\alpha$-stimulated albumin permeability in podocyte monolayers. A monolayer of podocytes was created on collagencoated Transwell filters in a 24-well plate. Wells were treated with TNF $\alpha$ $(20 \mathrm{ng} / \mathrm{ml})$, PPS $(400 \mu \mathrm{g} / \mathrm{ml})$ or PPS plus TNF $\alpha$. FITC-labeled BSA was added to the cells and the amount of FITC-labeled BSA that passed through the cell layer was quantitated. Negative controls included unlabeled BSA or filters without cell layers. The experiments were repeated three times. Results shown are fluorescence intensity $2 \mathrm{~h}$ after the addition of FITC-BSA. The value of albumin flux through monolayer without TNF $\alpha$ or PPS treatment was arbitrarily defined as $100 \%$. ${ }^{* * P}<0.01$ vs control; ${ }^{\# \# P} P<0.01$ vs cells treated only with TNF $\alpha$.

mRNA expression in aging diabetic mice was decreased by PPS treatment. Moreover, TNF $\alpha$-induced upregulation of proinflammatory genes including MCP-1, RANTES, CXCL-1, MIP-2 and iNOS in proximal tubular cells and podocytes was largely blocked by PPS. As PPS decreased TNF $\alpha$-stimulated $\mathrm{I} \kappa \mathrm{B}$ phosphorylation and NF- $\kappa \mathrm{B}$ activation, this may be one mechanism of its suppression of TNF $\alpha$ action. Finally, PPS also decreased high glucose and AGE-mediated MCP-1 production and NF- $\kappa \mathrm{B}$ activation. Both hyperglycemia and elevated AGE are critically involved in inflammation in diabetes.

We observed extensive macrophage infiltration in kidneys of aging diabetic C57B6 mice. This was nearly completely prevented by PPS treatment. Macrophage depletion experiments have shown that macrophages are important in the development and progression of diabetic complications including nephropathy. ${ }^{33}$ Infiltrating macrophages may contribute to tissue damage and lead to fibrosis through the production of oxidants and release of proteases and cytokines. ${ }^{46,47}$ Although it is unclear how PPS treatment decreases macrophage infiltration, the reduction of macrophages may contribute to the effect of PPS on glomerular and tubulointerstitial lesions in aging diabetic mice.

Albuminuria, a hallmark of $\mathrm{DN}$, is an independent risk factor for progressive renal structural damage. ${ }^{29,48}$ Although increased TNF $\alpha$ has been proposed to be correlated with the degree of albuminuria in $\mathrm{DN}^{49}$ there is no direct evidence of $\mathrm{TNF} \alpha$ for this at present. The current findings that
TNF $\alpha$-treatment increased the permeability of podocytes monolayers on Transwell filters to albumin, provides some support for this postulate. The fact that PPS decreased the $\mathrm{TNF} \alpha$-mediated increase in albumin permeability in the podocyte monolayers, suggests that this may be one action accounting for the reduction of albuminuria by PPS. Tubular injury may also have an important role in albuminuria. In this study, we have also observed intensive albumin staining in tubules of aging diabetic mice. As PPS-treated aging diabetic mice have visibly decreased tubular albumin staining, a protection against tubular injury may also contribute to decreased albuminuria in PPS-treated mice.

We have found that C57B6 mice develop a slowly progress kidney aging that begins at 18-20 months of age. The obvious albuminuria and renal fibrosis are present at 28-30 months of aging. Additional injury such as diabetes accelerates the process of kidney aging in C57B6 mice. In this study, PPS was shown to decrease diabetic injury in 22-month-old mice. It would be interesting for future experiments to examine if PPS decrease the process of normal kidney aging.

In conclusion, this study shows that PPS treatment prevents the progression of nephropathy in streptozotocininduced diabetes in aging C57B6 mice by decreasing albuminuria, renal macrophage infiltration and TNF- $\alpha$ expression. These effects were associated with improvement of histopathologic changes and renal function. Although the mechanisms of action may be complex, PPS suppresses inflammation mediated by $\mathrm{TNF} \alpha$, high glucose and AGEs. Since PPS has been widely used for the treatment of interstitial cystitis for nearly 20 years, and has few major side effects, it may be an additional agent that is worthy of further investigation for the treatment of DN. PPS has been shown to be with an excellent long-term safety profile. A 2-year study by National Toxicology Program shows no obvious toxicity in mice fed with PPS below $504 \mathrm{mg} / \mathrm{kg} /$ day (http://ntp.niehs. nih.gov/ntp/htdocs/LT_rpts/tr512.pdf). Thus, although from pharmacokinetic point of view that the bioavailability of PPS as an oral medicine is low, the wide window of its dosage range may be sufficient to offset this limit. ${ }^{50}$

\section{ACKNOWLEDGEMENTS}

This work is supported by NIH Grant 5R01AG027628-03 and Genzyme Grant to Feng Zheng, and JDRF 17-2008-1041 to Feng Zheng and Gary Striker.

\section{DISCLOSURE/CONFLICT OF INTEREST}

This work was also supported in part by SWATI to Dr Vlassara H SWATI has commercial interests in the development of anti-inflammatory drugs. None of the other co-authors have any relationship with SWATI. No other conflict of interest relevant to this article were reported.

1. US Renal Data System. USRDS (2007) Annual Data Report. The National Institutes of Health, National Institute of Diabetes and Digestive and Kidney Diseases: Bethesda, MD, 2007.

2. Düsing R, Sellers F. ACE inhibitors, angiotensin receptor blockers and direct renin inhibitors in combination: a review of their role after the ONTARGET trial. Curr Med Res Opin 2009;25:2287-2301. 
3. Estacio RO. Renin-angiotensin-aldosterone system blockade in diabetes: role of direct renin inhibitors. Postgrad Med 2009;121:33-44.

4. Abassi Z, Winaver J, Feuerstein GZ. The biochemical pharmacology of renin inhibitors: implications for translational medicine in hypertension, diabetic nephropathy and heart failure: expectations and reality. Biochem Pharmacol 2009;78:933-940.

5. Mauer M, Zinman B, Gardiner R, et al. Renal and retinal effects of enalapril and losartan in type 1 diabetes. N Engl J Med 2009;361:40-51.

6. Noh H, King GL. The role of protein kinase $C$ activation in diabetic nephropathy. Kidney Int Suppl 2007;106:S49-S53.

7. Navarro-González JF, Mora-Fernández C. The role of inflammatory cytokines in diabetic nephropathy. J Am Soc Nephrol 2008;19:433-442.

8. Nishikawa T, Edelstein D, Du XL, et al. Normalizing mitochondrial superoxide production blocks three pathways of hyperglycaemic damage. Nature 2000;404:787-790.

9. Tan AL, Forbes JM, Cooper ME. AGE, RAGE, and ROS in diabetic nephropathy. Semin Nephrol 2007;27:130-143.

10. Tuttle KR. Linking metabolism and inflammation and immunology: diabetic nephropathy is an inflammatory disease. J Am Soc Nephrol 2004;16:1537-1538.

11. Mora C, Navarro JF. Inflammation and diabetic nephropathy. Curr Diabetes Rep 2006;6:463-468.

12. Cheng HF, Wang CJ, Moeckel GW, et al. Cyclooxygenase-2 inhibitor blocks expression of mediators of renal injury in a model of diabetes and hypertension. Kidney Int 2002;62:929-939.

13. Lloberas N, Cruzado JM, Franquesa M, et al. Mammalian target of rapamycin pathway blockade slows progression of diabetic kidney disease in rats. J Am Soc Nephrol 2006;17:1395-1404.

14. Nickel JC, Barkin J, Forrest J, et al. Randomized, double-blind, doseranging study of pentosan polysulfate sodium for interstitial cystitis. Urology 2005;65:654-658.

15. Sadhukhan PC, Tchetgen MB, Rackley RR, et al. Sodium pentosan polysulfate reduces urothelial responses to inflammatory stimuli via an indirect mechanism. J Urol 2002;168:289-292.

16. Becker M, Franz G, Alban S. Inhibition of PMN-elastase activity by semisynthetic glucan sulfates. Thromb Haemost 2003;89:915-925.

17. Klegeris A, Singh EA, McGeer PL. Effects of C-reactive protein and pentosan polysulphate on human complement activation. Immunology 2002;106:381-388.

18. Bobadilla NA, Tack I, Tapia E, et al. Pentosan polysulfate prevents glomerular hypertension and structural injury despite persisting hypertension in 5/6 nephrectomy rats. J Am Soc Nephrol 2001;12 2080-2087.

19. Zheng F, Striker GE, Esposito C, et al. Strain differences rather than hyperglycemia determine the severity of glomerulosclerosis in mice. Kidney Int 1998;54:1999-2007.

20. Zheng $F$, Plati AR, Potier $M$, et al. Resistance to glomerulosclerosis in $B 6$ mice disappears after menopause. Am J Pathol 2003;162:1339-1348.

21. Yuen PS, Dunn SR, Miyaji T, et al. A simplified method for HPLC determination of creatinine in mouse serum. Am J Physiol Renal Physiol 2004;286:F1116-F1119.

22. Toyoda M, Najafian B, Kim Y, et al. Podocyte detachment and reduced glomerular capillary endothelial fenestration in human type 1 diabetic nephropathy. Diabetes 2007;56:2155-2160.

23. Neilson EG, McCafferty E, Feldman A, et al. Spontaneous interstitial nephritis in kdkd mice. I. An experimental model of autoimmune renal disease. J Immunol 1984;133:2560-2565.

24. Wu J, Zhang $\mathrm{R}$, Torreggiani $\mathrm{M}$, et al. Induction of diabetes in aged C57B6 mice results in severe nephropathy: an association with oxidative stress, endoplasmic reticulum stress, and inflammation. Am J Pathol 2010;176:2163-2176.

25. Wolf G, Neilson EG. Angiotensin II induces cellular hypertrophy in cultured murine proximal tubular cells. Am J Physiol 1990;259:F768F777.

26. Zheng F, Fornoni A, Elliot SJ, et al. Upregulation of type I collagen by TGF-beta in mesangial cells is blocked by PPARgamma activation. Am J Physiol 2002;282:F639-F648.

27. Zhao J, Kong HJ, Li H, et al. IRF-8/interferon (IFN) consensus sequencebinding protein is involved in Toll-like receptor (TLR) signaling and contributes to the cross-talk between TLR and IFN-gamma signaling pathways. J Biol Chem 2006;281:10073-10080.
28. Catanuto P, Doublier S, Lupia E, et al. 17 Beta-estradiol and tamoxifen upregulate estrogen receptor beta expression and control podocyte signaling pathways in a model of type 2 diabetes. Kidney Int 2009;75:1194-1201.

29. Russo LM, Sandoval RM, McKee M, et al. Albuminuria in diabetes is due to dysfunction of proximal tubular cell processing and not changes in albumin filtration. J Am Soc Nephrol 2009;20:489-494.

30. Jarad G, Miner JH. Albuminuria, wherefore art thou? J Am Soc Nephrol 2009;20:455-457.

31. Kralik PM, Long $Y$, Song $Y$, et al. Diabetic albuminuria is due to a small fraction of nephrons distinguished by albumin-stained tubules and glomerular adhesions. Am J Pathol 2009;175:500-509.

32. Gu L, Hagiwara S, Fan Q, et al. Role of receptor for advanced glycation end-products and signalling events in advanced glycation endproduct-induced monocyte chemoattractant protein-1 expression in differentiated mouse podocytes. Nephrol Dial Transplant 2006;21:299-313.

33. Sassy-Prigent C, Heudes D, Mandet C, et al. Early glomerular macrophage recruitment in streptozotocin-induced diabetic rats. Diabetes 2000;49:466-475.

34. Yozai K, Shikata K, Sasaki M, et al. Methotrexate prevents renal injury in experimental diabetic rats via anti-inflammatory actions. J Am Soc Nephrol 2005;16:3326-3338.

35. Lewis A, Steadman R, Manley $\mathrm{P}$, et al. Diabetic nephropathy, inflammation, hyaluronan and interstitial fibrosis. Histol Histopathol 2008;23:731-739.

36. Chow FY, Nikolic-Paterson DJ, Ma FY, et al. Monocyte chemoattractant protein-1-induced tissue inflammation is critical for the development of renal injury but not type 2 diabetes in obese $\mathrm{db} / \mathrm{db}$ mice. Diabetologia 2007;50:471-480.

37. Chow FY, Nikolic-Paterson DJ, Ozols E, et al. Monocyte chemoattractant protein-1 promotes the development of diabetic renal injury in streptozotocin-treated mice. Kidney Int 2006;69:73-80.

38. Chow FY, Nikolic-Paterson DJ, Ozols E, et al. Intercellular adhesion molecule-1 deficiency is protective against nephropathy in type 2 diabetic db/db mice. J Am Soc Nephrol 2005;16:1711-1722.

39. Okada S, Shikata K, Matsuda M, et al. Intercellular adhesion molecule-1deficient mice are resistant against renal injury after induction of diabetes. Diabetes 2003;52:2586-2593.

40. Panchapakesan U, Chen XM, Pollock CA. Drug insight: thiazolidinediones and diabetic nephropathy-relevance to renoprotection. Nat Clin Pract Nephrol 2005;1:33-43.

41. Sarafidis PA, Bakris GL. Protection of the kidney by thiazolidinediones: an assessment from bench to bedside. Kidney Int 2006;70:1223-1233.

42. Utimura R, Fujihara CK, Mattar AL, et al. Mycophenolate mofetil prevents the development of glomerular injury in experimental diabetes. Kidney Int 2003;63:209-216.

43. Apostolaki $M$, Armaka $M$, Victoratos $P$, et al. Cellular mechanisms of TNF function in models of inflammation and autoimmunity. Curr Dir Autoimmun 2010;11:1-26.

44. Khan SB, Cook HT, Bhangal G, et al. Antibody blockade of TNF-alpha reduces inflammation and scarring in experimental crescentic glomerulonephritis. Kidney Int 2005;67:1812-1820.

45. Ho AW, Wong CK, Lam CW. Tumor necrosis factor-alpha up-regulates the expression of CCL2 and adhesion molecules of human proximal tubular epithelial cells through MAPK signaling pathways. Immunobiology 2008;213:533-544.

46. Tesch GH. Role of macrophages in complications of type 2 diabetes. Clin Exp Pharmacol Physiol 2007;34:1016-1019.

47. Kelly DJ, Chanty A, Gow RM, et al. Protein kinase Cbeta inhibition attenuates osteopontin expression, macrophage recruitment, and tubulointerstitial injury in advanced experimental diabetic nephropathy. J Am Soc Nephrol 2005;16:1654-1660.

48. Jefferson JA, Shankland SJ, Pichler RH. Proteinuria in diabetic kidney disease: a mechanistic viewpoint. Kidney Int 2008;74:22-36.

49. Kalantarinia K, Awad AS, Siragy HM. Urinary and renal interstitial concentrations of TNF-alpha increase prior to the rise in albuminuria in diabetic rats. Kidney Int 2003;64:1208-1213.

50. Simon M, McClanahan RH, Shah JF, et al. Metabolism of [3H]pentosan polysulfate sodium (PPS) in healthy human volunteers. Xenobiotica 2005;35:775-784. 